\title{
PENJARA NAGARI SEBAGAI HUKUMAN ADAT DAN UPAYA MASYARAKAT NAGARI TIGO JANGKO DALAM MENANGGULANGI PERZINAAN
}

\author{
Salma \\ Institut Agama Islam Negeri Imam Bonjol Padang, Indonesia \\ E-mail: salma_nathiqa@yahoo.com \\ Solihin \\ Institut Agama Islam Negeri Imam Bonjol Padang, Indonesia \\ E-mail: miceljonireamon@gmail.com
}

\begin{abstract}
This article deals with Penjara Nagari as a place to quarantine a couple who committed an adultery or fornication in Nagari Tigo Jangko. The study attempts to explore the reasons of the people to build a jail, regardless the existing government's jails. The research found that the Penjara Nagari was built based on the decision of the kerapatan adat to anticipate and educate people to avoid adultery and fornication which were forbidden by Islamic law and Minangkabau tradition. The people caught the couple directly at the location. They screamed, humiliated and hit them. Then they brought the couple to the Penjara Nagari and few of people interrogated the couple and let the other people saw them in the jail. The prisoning of the couple had continued until kerapatan adat had made a decision which contained some punishments for the couple. Usually the prisoning occurred all night long till morning. Penjara Nagari in Islamic and Indonesian legal perspective was not real jail, since the real jail was built for prisoners who got a justice procedure and punishment from the court.
\end{abstract}

Keywords: Jail; nagari; adultery; fornication; punishment.

\section{Pendahuluan}

Kajian ini berkaitan dengan hukuman penjara sebagai hukuman adat. Tuntutan penerapan dan penegakan hukuman merupakan cara efektif untuk meminimalisasi dan mencegah terjadinya tindakan kriminal. Di antaranya adalah hukuman terhadap pelaku zina, pencurian, pembunuhan, dan tindakan pidana lainnya. Hukuman berfungsi sebagai salah satu alat untuk menanggulangi kejahatan. 
Dalam lintasan sejarah, hukuman mengalami perubahan dan perkembangan. Dari satu cara yang bersifat pembalasan terhadap orang-orang yang melakukan kejahatan, kemudian menjadi alat untuk melindungi individu dari gangguan individu lainnya dalam masyarakat. Hukuman yang berfungsi melindungi masyarakat dari gangguan kejahatan juga terus berubah dan berkembang ke arah fungsi hukuman itu sendiri (khususnya hukuman penjara) sebagai wadah pembinaan bagi narapidana sebelum nantinya mereka kembali ke dalam masyarakat. ${ }^{1}$

Hukuman perlu dilaksanakan sesuai dengan ketentuan-ketentuan yang telah dibuat. Tujuannya adalah untuk menanggulangi kejahatan dalam masyarakat dan untuk terciptanya rasa aman dan rasa keadilan. Hukuman juga menjadi alat bagi orang yang melakukan tindak kejahatan supaya orang itu berubah menjadi individu yang baik dan juga bisa melindungi individu lainnya dari kejahatan. Manifestasi fungsi hukuman sebagai alat pembalasan dendam berupa hukuman mati dan penjara dengan penyiksaaan-penyiksaan berkembang ke arah hukuman sebagai alat perlindungan masyarakat. Hal ini sekaligus menghilangkan gambaran narapidana yang hidup diasingkan dalam penjara-penjara yang terpencil dan mengalami penderitaan serta ketidakwajaran. Baru setelah hukuman berfungsi sebagai wadah pembinaan dan pendidikan, maka dicita-citakanlah suatu kehidupan hukuman penjara yang bersifat mendidik penghuninya, untuk bergaul seperti apa yang terdapat dalam masyarakat dengan sebisa mungkin menghindarkaan penderitaan. ${ }^{2}$

Menurut pengertian bahasa, penjara berarti bangunan tempat mengurung orang hukuman. ${ }^{3}$ Penjara menurut Pasal 1 ayat 1 Kitab Undang-Undang Hukum Pidana (KUHP) Pemasyarakatan adalah kegiatan untuk melakukan pembinaan warga binaan pemasyarakatan berdasarkan sistem, kelembagaan, dan cara pembinaan yang merupakan bagian akhir dari sistem pemidanaan dalam tata peradilan pidana. ${ }^{4}$ Lebih lanjut, pidana penjara diatur dalam Pasal 12 KUHP yang menegaskan:

Pidana penjara adalah seumur hidup atau selama waktu tertentu. Pidana

1 Soedjono Dirdjosisworo, Sejarah dan Asas-asas Penologi Pemasyarakatan (Bandung: Armico, 1991), 11.

2 Ibid., 12.

3 W.J.S. Poerwadarminta, Kamus Umum Bahasa Indonesia (Jakarta: Balai Pustaka, 2014), 732.

${ }^{4}$ Undang-Undang Republik. Indonesia Nomor 12 Tabun 1995 Tentang Pemasyarakatan. 
penjara selama waktu tertentu paling pendek adalah satu hari dan paling lama lima belas tahun berturut-turut. Pidana penjara selama waktu tertentu boleh dijatuhkan untuk dua puluh tahun berturut-turut dalam hal kejahatan yang pidananya hakim boleh memilih antara pidana mati, pidana seumur hidup, dan pidana penjara dalam waktu tertentu. Pidana penjara selama waktu tertentu sekali-sekali tidak boleh melebihi dua puluh tahun. $^{5}$

Istilah hukuman penjara (hukuman dalam bentuk biasa hukuman mati atau hukuman denda) sifat dan coraknya dalam memperlakukan orang-orang yang dihukum di dalamnya mengalami perkembangan dan merupakan suatu rentetan perjuangan panjang dalam perkembangan hukum pidana di berbagai negara. Dalam kriminologi, keberadaan penjara sangat besar peranannya dalam mengubah cara berpikir penguasa dan masyarakat umum dalam memberi makna tentang apa sebenarnya maksud dan tujuan dari hukuman penjara itu. ${ }^{6}$ Sejak abad ke-18 terjadi suatu perubahan yang berlangsung dalam peradilan. Dulu hakim tidak begitu memikirkan keadaan pribadi penjahat. Jika sudah terbukti kesalahannya, maka tinggal kewajiban para hakim untuk menjatuhkan hukuman.

Hukuman pada awalnya merupakan pembalasan dendam. Pada masyarakat yang sederhana, apabila ada anggotanya yang dirugikan, mereka langsung membalas kepada orang yang merugikan dengan menghukum orang yang merugikan tersebut. Setelah peran masyarakat makin besar maka timbul perubahan. Pembalasan dari pihak yang dirugikan mulai dilarang baik menurut kesusilaan yang ada dalam masyarakat maupun menurut hukum pidana. Akhirnya, masalah hukuman sepenuhnya dijatuhkan oleh negara. Pada perkembangan selanjutnya, penjara dipandang sebagai cara yang mengandung unsur memuaskan rasa dendam dan benci para anggota suatu kelompok yang dirugikan. Penjara juga melindungi masyarakat, agar masyarakat terhindar dari gangguan penjahat, sehingga penjahat ditindak/dihukum dan diisolir dari masyarakat. ${ }^{7}$

Dari pemaparan di atas diketahui adanya pandangan bahwa hukuman penjara merupakan pembalasan serta bentuk pemuasan rasa dendam masyarakat terhadap penjahat dan isolasi terhadap penjahat sebagai tindakan untuk melindungi masyarakat. Di Indonesia, aturan yang mengatur tentang penjara adalah Undang-Undang Republik

5 Tim Perumus, KUHP dan KUHAP (Surabaya: Kesindo Utama, 2010).

${ }^{6}$ Dirdjosisworo, Sejarah dan Asas-asas, 181.

${ }^{7}$ Ibid. 
Indonesia Nomor 12 Tahun 1995 Tentang Pemasyarakatan. Penjara dibuat oleh pemerintah dan dikelola oleh pemerintah secara resmi. ${ }^{8}$ Walaupun demikian, pada satu wilayah nagari di Minangkabau disediakan satu tempat untuk mengurung orang yang tertangkap berzina. Masyarakat menyebut tempat itu sebagai Penjara Nagari.

Kertaas kerja ini merupakan hasil penelitian lapangan (field research) dengan pendekatan kualitatif. Menurut Bungin, pendekatan kualitatif terletak pada upaya memecahkan makna berdasarkan objek kajiannya. ' Berdasarkan hal tersebut, maka penelitian ini berupaya menemukan makna-makna didirikan dan dipenjarakannnya pelaku zina di Penjara Nagari yang dibangun oleh pemuka masyarakat Nagari Tigo Jangko. Sumber data yang digunakan adalah data primer dan data sekunder.

Pengumpulan data dilakukan dengan menggunakan teknik observasi, wawancara, dan dokumentasi. Wawancara dilakukan pada informan kunci sebagai sumber data primer yang terdiri dari pelaku perzinaan, perangkat kerapatan adat yang terdiri dari pemerintahan nagari (wali nagari dan sekretaris), ninik mamak (pemangku adat/kepala suku), baik ninik mamak si pelaku maupun ninik mamak suku lain yang ada di nagari Tigo Jangko, alim ulama (orang yang dituakan dalam urusan agama), cadiak pandai (kaum intelektual yang ada di nagari), bundo kanduang (kaum ibu) dan para pemuda nagari. Observasi diperlukan untuk melihat dan mengamati Penjara Nagari sebagai tempat untuk mengurung si pelaku zina. Hanya saja selama pengumpulan data (2014-2015) tidak terjadi (terungkap) kasus perzinaan, sehingga tidak bisa diobservasi proses pemenjaraan si pelaku ke dalam Penjara Nagari ini. Dokumentasi juga digunakan sebagai teknik pengumpulan data. Dalam hal ini digunakan dokumen untuk mengetahui profil nagari, dasar hukum pengadaan Penjara Nagari, dokumen foto-foto Penjara Nagari, dan dokumen lainnya.

Analisis data penelitian menggunakan beberapa cara. Pertama, data dianalisis secara deskriptif. Penelitian deskriptif merupakan penelitian yang dimaksudkan untuk mengumpulkan informasi mengenai status suatu gejala yang ada, yaitu keadaan gejala menurut apa adanya pada saat penelitian dilakukan. ${ }^{10}$ Untuk memperkuat deskripsi digunakan tahapan seperti yang disampaikan oleh Miles dan Hubermen yaitu

${ }^{8}$ Undang-Undang Republik Indonesia Nomor 12 Tabun 1995 Tentang Pemasyarakatan.

${ }^{9}$ Burhan Bungin, Penelitian Kualitatif (Jakarta: Kencana, 2007), 5.

${ }^{10}$ Suharsimi Arikunto, Manajemen Penelitian (Jakarta: Rineka Cipta, 1993), 309. 
reduksi data, penyajian data verifikasi (menarik kesimpulan). ${ }^{11}$ Reduksi data di sini adalah proses pemilihan, pemusatan perhatian pada penyederhanaan, pengabstrakan dan transformasi data kasar yang muncul dari catatan-catatan tertulis dalam mengolah data lapangan. Penyajian data di sini adalah sekumpulan informasi dari pelaku zina, perangkat nagari, alim ulama, ninik mamak, para pemuda dan komponen masyarakat lainnya yang memberi kemungkinan adanya penarikan kesimpulan dan pengambilan tindakan seperti menyajikan data secara naratif. Langkah terakhir adalah melakukan verifikasi atau menarik kesimpulan. Agar data yang dikemukakan lebih akurat digunakan juga analisis silang dengan mengecek informasi dari berbagai sumber baik dari si pelaku zina yang pernah dihukum di Penjara Nagari, dari ninik mamak, perangkat nagari, ulama maupun masyarakat umum.

\section{Penjara dalam Sistem Hukum Pidana Indonesia}

Sejak abad ke-18 terlihat adanya suatu perubahan yang berlangsung dalam peradilan. Penderitaan narapidana di penjarapenjara dan para tahanan yang belum tentu bersalah serta orang-orang yang hanya karena hutang meringkuk di penjara, kesemua itu telah mendorong para pemikir-di antaranya John Howard (seorang kriminolog) —untuk berjuang meringankan penderitaan orang-orang yang dipenjara dan yang ditahan, baik dengan protes-protesnya, maupun dalam tulisan-tulisannya. Bahkan secara fisik, Howard keluar masuk penjara untuk melihat langsung dan menolong para nara pidana. Dalam dunia penologi, Howard dipandang sebagai pembaharu sistem kepenjaraan terbesar dalam sejarah. ${ }^{12}$

Akhir abad ke-19 dan awal abad ke-20 dan seterusnya, atas dasar pengaruh para ahli penologi, ahli hukum pidana dan ahli kriminologi, pemerintah mengadakan perbaikan ke arah usaha rehabilitasi (pembinaan dan pendidikan narapidana). Tujuan dari (penjara) adalah penjeraan. Penderitaan mulai lebih dipandang sebagai suatu akibat yang tidak dapat dihindarkan dari adanya tujuan yang rasional dari lembaga dan perlakuan terhadap narapidana yang tidak berkemanusian.

Gambaran bui dan penjara pada zaman kolonial di Indonesia penuh dengan penderitaan dan menyeramkan. Sisa-sisanya masih

${ }_{11}$ Mathew B. Miles dan A. Michael Hubermen, Analisis Data Kualitatif, terj. Tjetjep Rohendi Rohidi (Jakarta: UI Press, 1992), 16-19.

12 Undang-Undang Republik Indonesia Nomor 12 Tabun 1995 Tentang Pemasyarakatan. 
terlihat pada bangunan penjara dengan sel-selnya. Situasi ini secara resmi telah diakhiri dengan peletakan batu pertama pada tahun 1963 di Bandung yaitu orang-orang yang dinyatakan bersalah itu masuk ke dalam kamar-kamar penjara. Sahardjo menyatakan bahwa tujuan pidana penjara adalah pemasyarakatan yang mengandung makna bahwa tidak hanya masyarakat yang diayomi dari diulanginya perbuatan jahat oleh terpidana, melainkan juga orang-orang tersesat yang perlu dimasyarakatkan, sehingga dapat menjadi orang yang bermanfaat dalam masyarakat Indonesia. ${ }^{13}$ Jadi, dari uraian di atas dipahami bahwa bui atau penjara yang ada pada zaman kolonial Belanda di Indonesia yang penuh dengan penderitaan telah diakhiri dan diganti menjadi lembaga permasyarakatan.

Meskipun demikian, dalam pelaksanaannya masih terdapat beberapa masalah penting seperti gedung-gedung penjara peninggalan kolonial yang masih tetap digunakan. Tempat ini perlu diubah sesuai dengan cita-cita pemasyarakatan dan pasti memerlukan biaya yang besar sekali. Ada juga petugas-petugas lembaga pemasyarakatan yang masih sedikit dan belum memahami tujuan pemasyarakatan secara maksimal. Selain itu masyarakat masih sukar menerima narapidana setelah keluar dari lembaga pemasyarakatan. ${ }^{14}$

Pidana penjara sangat mirip dengan pidana kurungan, karena tempat pelaksanaannya sama, yaitu di lembaga pemasyarakatan. Namun bila dilihat dari segi operasionalisasi/praktik pelaksanaannya terdapat perbedaan, yaitu:

a. Pidana penjara biasanya diancamkan pada kejahatan yang sifatnya serius/berat seperti pembunuhan, sedangkan pidana kurungan biasanya diancamkan pada delik-delik yang bersifat ringan.

b. Orang yang menjalani pidana penjara dapat dipindahkan ke lembaga pemasyarakatan.

c. Pekerjaan orang yang dipidana penjara lebih berat dari pekerjaan orang yang dipidana kurungan.

d. Pakaian orang yang dipidana penjara harus seragam, sedangkan orang yang dipidana kurungan tidak memerlukan seragam.

e. Orang yang dipidana penjara tidak memiliki hak Pistole (hak memperbaiki kondisi, sarana/fasilitas di LP dengan biaya sendiri), sedangkan orang yang dipidana kurungan memiliki hak untuk itu.

f. Dalam pelaksanaan pidana penjara, dimungkinkan pelaksanaan

13 Ibid., 185.

${ }^{14}$ Dirdjosisworo, Sejarah dan Asas-asas, 181-185. 
konsep pidana penjara bersyarat sedang dalam pidana kurungan tidak demikian adanya. ${ }^{15}$

Lamintang mengemukakan bahwa pidana penjara adalah suatu pidana berupa pembatasan kebebasan bergerak dan seorang terpidana yang dilakukan dengan menutup orang tersebut di dalam sebuah lembaga pemasyarakatan. Caranya adalah mewajibkan orang itu untuk menaati semua peraturan tata tertib yang berlaku di dalam lembaga pemasyarakatan yang dikaitkan dengan suatu tindakan tata tertib bagi mereka yang telah melanggar peraturan tersebut. ${ }^{16}$

Roeslan menyatakan bahwa pidana penjara adalah pidana utama di antara pidana kehilangan kemerdekaan. Pidana penjara boleh dijatuhkan untuk seumur hidup atau untuk sementara waktu. ${ }^{17}$ Barda juga menyatakan pidana penjara tidak hanya mengakibatkan perampasan kemerdekaan, melainkan juga menimbulkan akibat negatif terhadap hal-hal yang berhubungan dengan dirampasnya kemerdekaan itu sendiri. Akibat negatif itu antara lain, terampasnya kehidupan seksual yang normal dari seorang narapidana, sehingga ada terjadi perilaku seksual menyimpang di kalangan terpidana. ${ }^{18}$ Pidana penjara memberikan stigma negatif yang akan terbawa terus walaupun yang bersangkutan tidak lagi melakukan kejahatan. Akibat lain yang sering disoroti ialah pengalaman penjara dapat menyebabkan degradasi derajat dan harga diri manusia. ${ }^{19}$

Andi menyatakan pidana penjara adalah bentuk pidana yang berbentuk kehilangan kemerdekaan. Pidana kehilangan kemerdekaan itu bukan hanya dalam bentuk pidana penjara tetapi juga berupa pengasingan seperti di Rusia, yaitu pengasingan ke Siberia dan juga berupa pembuangan ke seberang lautan. Dahulu para penjahat dibuang ke Australia. Pada zaman kolonial di Indonesia dikenal sistem pengasingan yang didasarkan pada hak istimewa gubernur jenderal (exorbitance). Misalnya pengasingan Mohammad Hatta dan Sutan

${ }_{15}$ Makhrus Munajat, Hukum Pidana Islam di Indonesia (Yogyakarta: Bidang Akademik UIN Sunan Kalijaga, 2008), 204.

16 P.A.F. Lamintang, Hukum Penitensier Indonesia (Bandung: Armiko, 1984), 69.

${ }^{17}$ Roeslan Saleh, Stelsel Pidana Indonesia (Jakarta: Aksara Baru, 1987), 62.

18 Aman menyebutkan bahwa 6\% dari narapidana laki-laki dan 4\% dari narapidana perempuan di lembaga pemasyarakatan dan rumah tahanan seluruh Indonesia pernah melakukan hubungan seksual. Lihat Muqowimul Aman, Prevalensi HIV dan Sifilis serta Perilaku Berisiko Terinfeksi HIV pada Narapidana di Lembaga Pemasyarakatan dan Rumah Tahanan di Indonesia (Jakarta: Kemenkumham, 2010), 2.

${ }_{19}$ Barda Nawawi Arief, Kebijakan Legislatif dengan Pidana Penjara (Semarang: Badan Penerbit UNDIP, 1996), 44. 
Syahrir ke Boven Digoel kemudian ke Neira. Pengasingan Soekarno ke Endeh kemudian ke Bengkulu. Adapun pidana penjara dewasa ini merupakan bentuk utama dan umum dari pidana kehilangan kemerdekaan. Dulunya pidana penjara tidak dikenal di Indonesia tetapi ada pidana pembuangan, pidana badan berupa pemotongan anggota badan atau dicambuk, ${ }^{20}$ pidana mati dan pidana denda atau berupa pembayaran ganti rugi. ${ }^{21}$ Jan Remmelink juga menyatakan bahwa pidana penjara adalah suatu bentuk pidana perampasan kemerdekaan (pidana badan) terpenting. Di Belanda syarat penjatuhannya dimuat dalam undang-undang Belanda atau BW yang baru Pasal 133 ayat 3 dengan menetapkan persyaratan bahwa terpidana hanya boleh dijatuhkan oleh hakim (pidana). ${ }^{22}$ Lebih lanjut pidana penjara diatur dalam Pasal 12 KUHP sebagaimana telah disebut di atas.

Berdasarkan uraian di atas, pada prinsipnya pidana penjara berkaitan erat dengan pidana perampasan kemerdekaan yang dapat memberikan label jahat dan dapat menurunkan derajat dan harga diri manusia. Hukuman penjara merupakan salah satu bentuk dari hukuman kemerdekaan dan bentuk yang lainnya adalah hukuman kurungan. Hukuman penjara lebih berat bila dibanding dengan hukuman kurungan. Penjara diancamkan terhadap kejahatankejahatan yang dilakukan secara sengaja. ${ }^{23}$ Hukuman penjara secara khusus ditujukan sebagai hukuman terhadap kejahatan-kejahatan yang karena sifatnya menunjukkan watak yang buruk dan nafsu yang jahat.

\footnotetext{
${ }^{20}$ Hazairin menjelaskan bahwa Peradilan Asli (Peradilan Adat) di Aceh di antaranya berwenang mengadili pidana Islam tetapi tidak bisa dilaksanakan lagi ketika penjajah Belanda melarang hukuman potong tangan dan kaki (mutilasi dalam sebutan Belanda) dalam Staatblad 1916: 432. Larangan yang sama juga diberlakukan pada wilayah Peradilan Agama Jawa dan Madura dalam Staatblad 1882-152. Tidak hanya itu, Belanda juga mengeluarkan larangan mutilasi dan hukuman siksa (dera) pada Peradilan Swapraja dalam Staatblad 1938-529 pasal 13: 3a. Akan tetapi hukuman cambuk dengan rotan dalam daerah Peradilan Gubernemen Hindia Belanda (Pengadilan Negeri) baru dihapuskan sejak dikeluarkannya Staatblad 1866-15, namun masih tetap diberlakukan sebagai hukuman disipliner bagi orang-orang dalam penjara. Lihat Hazairin, Tujuh Serangkai Tentang Hukum (Jakarta: Bina Aksara, 1981), 61-62.

${ }^{21}$ Andi Hamzah, Sistem Pidana dan Pemidanaan Indonesia (Jakarta: Pradnya Paramita, 1993), 36-37.

22 Jan Remmelink, Hukum Pidana Komentar atas Pasal-pasal Terpenting dari Kitab Undang-undang Hukum Pidana Belanda dan Paparannya dalam Undang-Undang Hukum Pidana Indonesia (Jakarta: Gramedia Pustaka Ulama, 2003), 465.

${ }^{23}$ Tirtaatmidjaja, Pokok-Pokok Hukum Pidana (Jakarta: Fasco, 1955), 124.
} 
Ada tiga sistem hukuman penjara, yaitu:

1. Sistem Pensylvania yang menghendaki para terhukum terusmenerus ditutup sendiri-sendiri dalam satu kamar atau sel.

2. Sistem Auburne yang menentukan bahwa para terhukum disuruh bekerja bersama-sama di siang hari tetapi tidak diperbolehkan berbicara satu sama lain.

3. Sistem Irlandia yang menghendaki para terhukum pada mulanya ditutup secara terus-menerus, tetapi kemudian disuruh bekerja secara bersama-sama, dan tahap demi tahap diberi kelonggaran bergaul satu sama lain sehingga pada akhirnya, setelah tiga perempat dari lamanya hukuman sudah lampau, maka dimerdekakan dengan syarat. ${ }^{24}$

Pengisolasian seorang terhukum secara terus-menerus berdasar pada anggapan bahwa seorang penjahat jika diperlakukan demikian maka ia akan merenungkan keadaan jiwanya dan selanjutnya akan mempermudah untuk memperbaiki diri. Apabila disuruh bergaul dengan terhukum yang lain, maka si terhukum justru akan berperilaku lebih jelek karena mereka akan saling mempengaruhi ke arah keadaan yang lebih buruk. Anggapan semacam ini tidak sepenuhnya diterima, karena ada sebagian orang yang beranggapan bahwa pengisolasian seorang terhukum justru akan mempertebal tabiatnya yang jahat dan pergaulan dengan orang lain akan mendekatkan jiwanya kepada keadaan masyarakat yang mengharapkan perbaikan tabiatnya.

Di Indonesia sendiri seolah-olah ketiga sistem tersebut disatukan. Biasanya beberapa orang terhukum dikumpulkan dalam satu ruangan. Tidak hanya ketika bekerja tetapi ketika tidur juga bersama-sama, sekalipun ada kemungkinan terhukum yang nakal dapat ditutup sendiri dalam satu kamar atau sel. Menurut Pasal 15 KUHP, seorang terhukum penjara atau kurungan yang dua pertiga dari lamanya hukuman sudah dijalani dan tenggang ini paling sedikit sembilan bulan, dapat dimerdekakan dengan syarat dan dalam waktu percobaan. Lamanya satu tahun lebih dari sisa lamanya hukuman. ${ }^{25}$

Dalam penjelasan KUHP Pasal 12 ayat 1 dan 2, pidana penjara dapat dijatuhkan untuk seumur hidup. Masyarakat merasa keberatan atas jenis pidana ini karena dengan putusan demikian itu terhukum tidak mempunyai harapan lagi untuk kembali ke masyarakat. Sering

\footnotetext{
${ }^{24}$ Wiryono Prodjodikoro, Asas-Asas Hukum Pidana di Indonesia (Bandung: Erwisco, 1989), 170.

${ }^{25}$ Ibid.
} 
pula harapan tersebut dapat dipulihkan dengan adanya lembaga grasi, yang dapat mengubah pidana penjara seumur hidup itu menjadi pidana penjara selama waktu tertentu. ${ }^{26}$

Menurut ayat 2 KUHP Pasal 12 disebutkan bahwa pidana penjara selama waktu tertentu paling pendek adalah satu hari dan yang paling lama adalah lima belas tahun berturut-turut. Selanjutnya setelah pidana penjara seumur hidup itu diubah menjadi pidana penjara sementara waktu, yang paling lama adalah lima belas tahun. Jika terhukum berkelakuan baik terus-menerus, dia dapat pula dibebaskan lagi pada tiap tanggal 17 Agustus, yaitu hari proklamasi kemerdekaan Indonesia.

Dalam KUHP Pasal 13 orang yang dijatuhi pidana penjara dibagibagi atas beberapa golongan (kelas). Dalam pasal tersebut dijelaskan bahwa orang yang dijatuhi pidana penjara dibagi dalam empat kelas. Tujuannya adalah agar orang-orang terhukum yang pada dasarnya adalah baik, tidak sampai terpengaruh oleh kebiasaan-kebiasaan jelek dari orang-orang terhukum lainnya. Hal tersebut juga dimaksudkan untuk mendorong orang-orang terhukum itu berkelakuan baik agar dapat meningkatkan perilakunya menjadi lebih baik lagi. ${ }^{27}$

Penjara kelas pertama merupakan orang yang dipidana dengan pidana penjara seumur hidup dan orang yang dipidana dengan pidana penjara sementara waktu yang tidak menuruti perintah atau yang berbahaya untuk keamanan pegawai-pegawai penjara maupun sesama orang terhukum. Orang terhukum dari kelas ini harus dipisahkan dari orang terhukum lainnya. Orang terhukum dari kelas ini yang pidananya adalah pidana sementara waktu, dapat dinaikkan ke kelas dua jika selama satu tahun ada kemajuan dalam berkelakuan baik. ${ }^{28}$ Penjara kelas kedua merupakan orang-orang terhukum yang dipidana dengan pidana penjara lebih dari tiga bulan. Adapun penjara kelas ketiga dimasukkan orang terhukum yang dipidana dengan pidana penjara setelah selama enam bulan berturut-turut berkelakuan baik dalam kelas dua. Penjara kelas empat adalah semua orang terhukum yang dipidana dengan pidana penjara tiga bulan atau kurang. Orangorang terhukum dari kelas tiga apabila telah menjalani pidananya sebanyak dua pertiga dari jumlah lamanya pidana dan sekurang-

26 Roeslan Saleh, Kitab Undang-undang Hukum Pidana dengan Penjelasannya (Jakarta: Aksara Baru, 1987), 29.

${ }^{27}$ Sugandhi, KUHP dengan Penjelasan (Surabaya: Usaha Nasional, 1980), 31.

${ }^{28}$ Moeljatno, Kitab Undang-undang Hukum Pidana (Jakarta: Bumi Aksara, 1972), 81. 
kurangnya sembilan bulan maka dapat diusulkan untuk dibebaskan bersyarat. Dalam praktiknya pembagian yang disebutkan di atas jarang dilaksanakan, karena penggolongan orang-orang terhukum dalam rumah penjara diukur dengan mengikuti penggolongan lamanya pidana yang harus dijalani atau jenis pidana yang dijalani. ${ }^{29}$

\section{Penjara dalam Hukum Islam}

Dalam khazanah hukum Islam, hukuman penjara biasa disebut dengan al-habs atau al-sijn. Secara etimologis kata itu berarti mencegah dan menahan. Secara terminologis kata itu bermakna menahan atau mencegah seseorang pelaku kejahatan dari pergaulan dengan masyarakat. ${ }^{30}$ Menurut hukum pidana Islam, penjara termasuk dalam kategori hukuman ta'zî atau hukuman yang ditentukan oleh hakim karena dalam al-Qur'ân dan Sunnah tidak diatur secara terperinci mengenai hukuman penjara. ${ }^{31} \mathrm{Ta}^{2}$ zî $^{\mathrm{i}}$ sendiri secara bahasa artinya pencegahan dan pertolongan. Kemudian kata ini sering digunakan untuk menunjukkan arti pendidikan dan pengajaran. ${ }^{32}$ Hal yang bisa dianggap menjadi dasar pidana penjara di antaranya adalah Q.S. alMâidah [5]: 33. Dalam ayat ini disebutkan lafal aw yunfaw min al-ard. Dalam tafsir disebutkan bahwa makna lafal itu adalah dipenjarakan. ${ }^{33}$ Ayat kedua yang bisa dijadikan landasan untuk pidana penjara adalah Q.S. al-Nisâ' [4]: 15. Dalam ayat ini dijelaskan hukuman bagi perempuan yang berzina yaitu ditahan dan dipenjarakan di dalam rumah mereka (al-imsâk, fì al-buyût). ${ }^{34}$ Ayat ini menerangkan bahwa kalau perempuan berbuat zina, maka hakim/pihak berwenang tidak boleh menuduhnya kecuali jika ada saksi empat orang laki-laki, sehingga perempuan itu dihukum dengan memenjarakannya dalam rumah hingga dia wafat atau bertobat. Dalam hadith yang diriwayatkan oleh 'Ubâdah b. Ṣâmit disebutkan bahwa hukuman bagi bujang dan perawan yang berzina adalah didera seratus kali dan

\footnotetext{
${ }^{29}$ Sugandhi, KUHP, 32-33.

${ }^{30}$ Waḥbah al-Zuhaylî, al-Figh al-Islâmî wa Adillatuh, Vol. 6 (Beirut: Dâr al-Fikr, 1989), 198.

${ }^{31}$ Ibid., 197.

32 'Abd al-Qâdir 'Awdah, al-Tashrî" al-jinâ'î al-Islâmî (Kairo: Maktabah Dâr al'Urûbah, 1963), 683.

33 Abû Bakr Aḥmad b. 'Alî al-Râzî al-Jașṣậ, Aḥkâm al-Qur'ân, Vol. 2 (Beirut: Dâr alFikr, t.th.), 412.

${ }^{34}$ Muhammad 'Alî al-Sâyis, Tafsîr Âyât al-Aḥkâm, Vol. 2 (t.t.: t.tp., t.th.), 55.
} 
dibuang ke wilayah lain. ${ }^{35}$ Penjelasan dibuang ke wilayah lain dalam hadith tersebut disebutkan oleh ulama bisa digantikan dengan hukuman penjara.

Hukuman kurungan/penjara merupakan hukuman yang bersifat pilihan yang diserahkan kepada hakim untuk memutuskannya. Hakim baru boleh menjatuhkan kurungan apabila hukuman itu bermanfaat bagi terpidana. Akibat perbedaan tersebut, jumlah terpidana kurungan di negara yang mempraktikkan hukum Islam sangat sedikit, sedangkan jumlah terpidana kurungan di negara yang mempraktikkan hukum konvensional sangat banyak. Dalam hal ini sistem hukuman di Indonesia menganut sistem konvensional dengan menetapkan hukuman penjara sebagai hukuman yang paling banyak dijatuhkan.

Khalifah 'Umar dalam masa pemerintahannya pernah membeli rumah Șafwân b. Umayyah dengan harga 4000 dirham untuk kemudian dijadikan sebagai penjara. ${ }^{36}$ Atas dasar kebijakan 'Umar tersebut, para ulama membolehkan pemerintah untuk membangun penjara. Alasan lain dibolehkanya hukuman penjara sebagai ta' $₹ \hat{\imath} r$ adalah tindakan Nabi Muhammad yang pernah memenjarakan beberapa orang di Madinah dalam tuntutan pembunuhan. Tindakan Khalifah 'Uthmân yang pernah memenjarakan Dabi' b. al-Hâtrith, salah satu pencuri dari Bani Tamîm, sampai dia mati di penjara. Demikian pula Khalifah 'Alî pernah memenjarakan 'Abd Allâh b. alZubayr di Mekah di mana pada akhirnya dia menolak untuk membaiat 'Alî sebagai khalifah pengganti 'Uthmân. ${ }^{37}$

Hukuman penjara dalam Islam dibagi menjadi dua bagian, pertama hukuman penjara terbatas. Hukuman penjara terbatas adalah hukuman penjara yang lama waktunya dibatasi secara tegas. Hukuman penjara ini diterapkan untuk hukuman penghinaan, penjual khamar, pemakan riba, melanggar kehormatan bulan suci Ramadan dengan terbuka pada siang hari tanpa uzur, mengairi ladang dengan air dari saluran tetangga tanpa izin, caci-mencaci antara dua orang yang berperkara di depan sidang pengadilan, dan saksi palsu. ${ }^{38}$

\footnotetext{
35 Muḥammad b. al-Amîr al-Ṣan'ânî, Subul al-Salâm, Vol. 4 (Bandung: Dahlan, t.th.), 5.

36 Abdul Azis Dahlan (ed.), Ensiklopedi Hukum Islam (Jakarta: Ichtiar Baru Van Hoeve, 1997), 71.

37 'Abd al-'Azîz Amîr, al-Ta'zîr fî al-Sharî'ah al-Islâmîyah (Mesir: Dâr al-Bâb al-Halabî wa Awlâduh, 1989), 362.

38 Barda Nawawi Arief, Pidana Penjara Terbatas: Suatu Gagasan Penggabungan antara
} 
Lamanya hukuman penjara tidak ada kesepakatan di kalangan para ulama. 'Abd al-'Azîz Amîr berpendapat bahwa lamanya penjara dua bulan atau tiga bulan, bisa kurang dan bisa lebih. Al-Mâwardî juga menyatakan bahwa hukuman penjara dalam ta' $₹ \hat{i}$ berbeda-beda, tergantung pada pelaku dan jenis hukumannya, di antara pelaku ada yang dipenjara selama satu hari dan ada pula yang lebih lama. ${ }^{39}$ Batas tertinggi untuk hukuman penjara terbatas ini juga tidak ada kesepakatan di kalangan fuqahâ'. Menurut ulama Shâfi'îyah, batas tertinggi untuk hukuman penjara terbatas ini adalah satu tahun. Mereka menyamakan dengan hukuman pengasingan dalam badd alzinâ yang lamanya hanya satu tahun dan hukuman ta' zîr tidak boleh melebihi hukuman hadd. Namun tidak semua ulama Shâfi'îyah berpendapat seperti demikian. Al-Mâwardî mengemukakan bahwa di antara para pelaku ada yang dikenakan hukuman penjara selama satu hari dan ada pula yang lebih lama sampai batas waktu yang tidak ditentukan, tergantung pada perbedaan pelaku dan hukumannya atau tingkat kejahatannya. ${ }^{40}$

Pendapat yang dinukil oleh 'Abd Allâh al-Zubayr menyebutkan bahwa bisa ditetapkan masa hukuman penjara dua bulan atau tiga bulan atau bisa kurang atau bahkan lebih lama lagi. Demikian pula Ibn al-Majașun dari ulama Mâlikîyah yang menetapkan lamanya hukuman yaitu setengah bulan, dua bulan atau empat bulan tergantung pada kadar harta yang ditahannya. ${ }^{41}$

Dari uraian di atas diketahui bahwa tidak ada batas tertinggi yang pasti dan dijadikan barometer hukuman penjara sebagai ta' ${ }^{\prime} \hat{\imath}$ r. Hal itu diserahkan kepada keputusan hakim dengan memperhatikan perbedaan kondisi pelaku, tingkat kejahatannya, hukuman, tempat, waktu dan situasi ketika hukuman itu terjadi. Adapun batas terendah dari hukuman penjara sebagai ta 'zîr juga tidak ada kesepakatan di kalangan ulama. Menurut sebagian ulama, seperti al-Mâwardî, batas terendah hukuman penjara adalah satu hari. Namun menurut Ibn Qudâmah tidak ada ketentuan yang pasti, melainkan diserahkan pada putusan hakim (ulu al-amr). ${ }^{42}$

\footnotetext{
Pidana Penjara dengan Pidana Pengawasan (Jakarta: Raja Grafindo Persada, 2002), 93.

39 Amîr, al-Ta'sîr, 363.

40 Abû al-Ḥasan 'Alî b. Muhammad b. Habî̉b al-Mâwardî, al-Aḥkâm al-Sultânîyah (Beirut: Dâr al-Fikr, 1966), 236.

${ }^{41}$ Munajat, Hukum, 205.

42 al-Mâwardî, al-Aḥkâm, 238.
} 
Kedua, hukuman penjara tidak terbatas. Hukuman penjara tidak terbatas dan tidak dibatasi waktunya, tetapi berlangsung terus sampai orang yang terhukum meninggal dunia, atau sampai dia bertobat. Dalam istilah lain disebut hukuman seumur hidup. Hukuman penjara seumur hidup dijatuhkan kepada penjahat yang sangat berbahaya, misalnya seseorang yang menahan orang lain untuk dibunuh oleh orang ketiga atau seperti orang yang mengikuti orang lain kemudian melemparkannya ke depan seekor harimau. Menurut Abû Yûsuf sebagaimana dikutip oleh Makhrus Munajat, apabila orang tersebut mati dimakan harimau, maka si pelaku dipidana penjara seumur hidup. ${ }^{43}$ Hukuman yang tidak terbatas jenis yang kedua (sampai ia bertobat) dikenakan antara lain untuk orang yang dituduh membunuh dan mencuri, melakukan homoseksual, penyihir, dan mencuri untuk ketiga kalinya.

Bila dicermati beberapa pendapat ulama tersebut di atas dapat dipahami sebenarnya dalam hukum pidana Islam tidak menutup kemungkinan diadakannya pidana penjara-sepanjang itu memang diperlukan. Apalagi pada masa Rasulullah pernah dipraktikkan suatu jenis $t a$ 'zir yang esensinya sangat mirip dengan pidana penjara, yaitu ta' ${ }^{\prime} \hat{\imath}$ r berupa pembuangan (al-nafy atau al-ib'âd) terhadap orang-orang yang menyerupai wanita. Imam Ahmad b. Hanbal pernah mengatakan bahwa laki-laki yang menyerupai perempuan (hukumannya adalah) dilenyapkan (diasingkan), karena dia tidak mendatangkan apa-apa kecuali kerusakan. Penguasa berhak untuk membuangnya ke daerah yang penduduknya dipandang aman dari dirinya. Jika penguasa khawatir tentang hal itu, maka boleh memenjarakan mereka. Esensi dari ta' $2 \hat{\imath}$ r pembuangan ini adalah untuk mengisolir pelaku kejahatan dari masyarakatnya agar dia tidak mempengaruhi yang lainnya, sebagaimana tampak dalam pernyataan Imam Ahmad di atas. Hal itu berarti bahwa esensi dari ta'zî tidak berbeda dari esensi pidana penjara dalam sistem hukum modern. ${ }^{44}$

Menurut Jimly Assiddiqie, pidana ta' $2 \hat{\imath}$ r pembuangan yang dipraktikkan pada zaman dahulu, untuk sekarang ini perlu dikaji relevansinya. Saat ini, perhubungan dan transportasi sudah tidak menjadi masalah. Berarti pidana pembuangan bisa dikatakan tidak punya arti sama sekali. Karena itu, mengingat esensi dari pembuangan

43 Makhrus Munajat, Reaktualisasi Pemikiran Hukum Pidana Islam (Yogyakarta: Cakrawala, 2006), 14.

${ }^{44}$ Ibid., 198. 
dan penjara adalah sama, yaitu isolasi dan pelajaran bagi pelaku kejahatan, pidana pembuangan atau pengasingan yang sudah kurang efektif ini perlu diganti dengan pidana penjara. ${ }^{45}$ Pidana penjara adalah bentuk pengembangan lebih lanjut dari pidana ta'zîr berupa pembuangan atau pengasingan. Substansinya adalah bagaimana agar

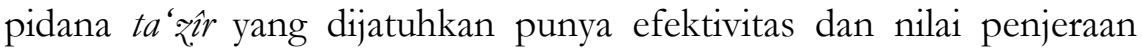
yang tinggi.

\section{Zina dalam Hukum Islam}

Perzinaan adalah salah satu perbuatan yang dilarang dalam Islam. Perzinaan termasuk ke dalam kategori jarimah budûd ${ }^{\text {t6 }}$ yaitu jarimah yang kadar hukumannya telah ditentukan oleh Allah dalam al-Qur'ân dan Sunnah. Oleh karena itu, hukuman bagi orang yang berzina sangat berat terutama jika pelaku telah pernah dan sedang dalam ikatan pernikahan sah. Pada tahap awal Allah melarang umat Islam untuk mendekati perbuatan zina yang dijelaskan dalam Q.S. al-Isrâ' [17]: 32 dan Q.S. al-Furqân [25]: 28-29. Dalam kedua ayat ini disebutkan larangan mendekati perzinaan dan dosa bagi orang yang melakukannya. Dalam ayat lain Allah menjelaskan hukuman bagi orang yang berzina. Ada tiga jenis hukuman yang diperintahkan oleh Allah dalam al-Qur'ân agar diberikan kepada orang yang berzina. Pertama, hukuman tahanan rumah (al-imsâk fì al-buyût) bagi para perempuan yang berzina. Hukuman ini dijelaskan dalam Q.S. al-Nisâ‘ [4]: 15. Hukuman ini bisa dilaksanakan jika empat orang saksi menyatakan bahwa perempuan tersebut memang benar telah melakukan perzinaan. Kedua, hukuman celaan dan cacian (al-iqấizyah) bagi orang yang berzina baik perzinaan yang terjadi antara laki-laki dan perempuan maupun perzinaan yang terjadi sesama jenis (homoseksual). ${ }^{47}$ Hukuman ini dijelaskan dalam Q.S. al-Nisâ' [4]: 16. Ketiga, hukuman dera sebanyak seratus kali bagi laki-laki dan perempuan yang berzina. Hukuman ini dijelaskan dalam Q.S. al-Nûr [24]: 2 dan dipertegas dengan keharusan empat orang saksi yang

\footnotetext{
45 Jimly Assiddiqie, Pembaharuan Hukum Pidana Indonesia (Bandung: Angkasa, 1996), 43.

${ }^{46} \mathrm{H}$ ududd menurut pengertian ahli fikih adalah hukuman yang telah ditentukan oleh syarak pada perbuatan maksiat tertentu dengan tujuan untuk mencegah terjadinya perbuatan yang sama. Lihat 'Alî 'Abd al-Raḥmân al-Hassûn, al-'Uqûbat al-Mukhtalaf 'alayhâ fì Jarâ'im al-Hudûd (Riyad: Dâr al-Nafâ'is, 2001), 26.

${ }^{47}$ Ibn Kathîr, Mukhtasar Tafsîr Ibn Kathîr, Vol. 1 (Beirut: Dâr al-Qur'ân, 1393 H), 366.
} 
menyaksikan terjadinya perzinaan itu dalam surat yang sama ayat 4 dan Q.S. al-Nisâ' [4]: 15.

Selain tiga bentuk hukuman di atas, dalam hadîth Rasulullah juga ditemukan dua bentuk hukuman lain bagi orang yang berzina. Pertama, didera seratus kali dan dibuang selama satu tahun (dipenjarakan) bagi bujangan dan perawan yang berzina. Hukuman buang ini digabung dan dilaksanakan beriringan dengan hukuman dera sebanyak seratus kali. ${ }^{48}$ Hadîth-hadîth ini diriwayatkan di antaranya oleh 'Ubâdah b. Șâmit. Kedua, hukuman rajm (dilempari dengan batu kerikil sampai mati) bagi orang yang berzina tetapi telah menikah dan pernah menikah. ${ }^{49}$ Hukuman rajm dan dera seratus kali ini juga digabung dan dilaksanakan beriringan kepada laki-laki dan perempuan menikah yang berzina. Hadîth yang menjelaskan hukuman ini diriwayatkan di antaranya oleh 'Umar b. al-Khattâb.

Berdasarkan penjelasan di atas diketahui bahwa dalam hukum Islam ditemukan setidaknya ada lima jenis hukuman bagi orang yang berzina yaitu tahanan rumah, cacian/celaan, dera seratus kali, dibuang selama satu tahun dan dilempari dengan batu kerikil sampai mati. Hukuman-hukuman ini bisa dilaksanakan jika terpenuhi syarat-syarat yang ditentukan oleh sharî́ah. Misalnya si pelaku zina adalah orang yang beragama Islam, baligh, berakal, dan tidak dalam keadaan terpaksa. Sementara syarat yang dikehendaki pada saksi di antaranya berjumlah empat orang laki-laki dan melihat dengan mata kepalanya sendiri.

Metode yang digunakan untuk membuktikan telah terjadi perzinaan setidak-tidaknya ada tiga yaitu kesaksian (al-shabâdab), pengakuan (al-iqrâr) dan indikasi (al-qarinah). Dalam Q.S. al-Nisâ' [4]: 15 disebutkan bahwa jumlah saksi yang dikehendaki untuk membuktikan telah terjadi perzinaan adalah empat orang saksi. Para ulama menjelaskan bahwa syarat-syarat saksi zina adalah beragama Islam, baligh, berakal, merdeka dan tidak dalam keadaan terpaksa. Secara khusus syarat-syarat saksi menjadi lebih spesifik seperti melihat hubungan seksual itu dengan matanya sendiri, terdiri dari empat orang laki-laki dan adil. ${ }^{50}$ Alat bukti yang kedua adalah pengakuan orang yang berzina. Secara umum dalam hadîth diungkapkan bahwa orang-

48 Zakariyâ 'Alî Yûsuf, al-Majmû' Sharh al-Muhadhdhab, Vol. 18 (Mesir: Maṭa'at alImâm, t.th.), 252.

${ }^{49}$ Ibn Qudâmah, al-Mughnî, Vol. 10 (Beirut: Dâr al-Kutub al-'Ilmîyah, 1985), 121.

${ }^{50}$ al-Zuhaylî, al-Figh al-Islâmî, 48. 
orang yang dilaksanakan hukuman ḥadd al-zinâ kepada mereka dibuktikan melalui pengakuan yang mereka sampaikan kepada Rasulullah. Hanya saja aspek yang diperdebatkan ulama adalah jumlah pengakuan yang harus mereka lakukan. ${ }^{51}$ Ada yang mengatakan pengakuan itu harus empat kali untuk mengukur kesebandingan dengan empat orang saksi dan ada yang megatakan satu kali pengakuan berzina sudah memadai untuk dibuktikan perzinaannya.

\section{Hukuman Adat Penjara Nagari di Nagari Tigo Jangko}

Nagari adalah adalah persekutuan hukum yang berdiri di atas dasar faktor teritorial (daerah) dan faktor genealogi (suku). Maksudnya, nagari itu tertentu batas-batasnya dan sekurang-kurangnya ada empat suku di dalamnya. ${ }^{52}$ Asal usul nagari sendiri melalui empat tahapan. Pertama, taratak yaitu daerah perumahan tempat penduduk nagari bersawah dan berladang bersama-sama. Lokasinya agak jauh dari nagari dengan satu gubuk tanpa ruangan dan tanpa surau. Kedua, dusun yaitu perluasan dari taratak. Di taratak penduduk tinggal di gubuk untuk sementara waktu dan di dusun penduduk sudah mulai menetap, karena anggota keluarga sudah mulai berkembang. Mereka mendirikan rumah-rumah tetapi tidak dalam bentuk rumah gadang karena keluarga belum memiliki ninik mamak (penghulu). Mereka mulai mendirikan surau untuk tempat beribadah. Ketiga, koto yaitu perluasan dari dusun. Keluarga yang tinggal dalam koto sudah semakin berkembang, sehingga terpecah dari suku asal dan memiliki ninik mamak (penghulu) sendiri sekalipun dalam jumlah kecil dan belum memenuhi kriteria nagari. Koto sudah memiliki rumah gadang sebagai tempat tinggal keluarga dan memiliki masjid sendiri untuk melaksanakan salat Jumat. Keempat, nagari yaitu perluasan dari koto dengan cara lebih sempurnanya susunan kemasyarakatan dalam koto. Kelompok genealogis setingkat suku sudah berjumlah lebih dari tiga, sehingga perlu didirikan balai adat sebagai tempat kegiatan kerapatan adat. ${ }^{53}$

51 Dalam Sahţh Muslim disebutkan bahwa seorang laki-laki datang ke hadapan Rasulullah s.a.w dan beliau sedang berada di masjid. Laki-laki itu mengaku telah berzina. Pengakuan itu diungkapkan kepada Rasulullah sebanyak empat kali dan Rasulullah melaksanakan hukuman ḅudûd kepadanya atas empat kali pengakuan itu. Lihat Abû al-Husayn Muslim b. al-Ḥajjâj al-Naysâbûrî, Șaḥ̂h Muslim (Beirut: Dâr alKutub al-'Ilmîyah, 2003), 670.

${ }^{52}$ Chairul Anwar, Hukum Adat Indonesia: Meninjau Hukum Adat Minangkabau (Jakarta: Rineka Cipta, 1997), 22.

53 Pembentukan tanah ulayat bersamaan dengan proses terbentuknya satu nagari. Oleh karena itu, di Minangkabau dikenal kepemilikan tanah dengan nama ulayat 
Dalam segala hal tidak berhubungan lagi dengan nagari asal. Di wilayah ini dilaksanakan pemerintahan sendiri dengan sumber daya sendiri. Oleh karena itu, satu nagari telah berdiri secara sempurna. Naim menyebutkan bahwa taratak berkembang menjadi dusun, dusun menjadi nagari, nagari menjadi koto, dan koto menjadi lubak. Ada tiga lubak di Sumatera Barat yang menjadi wilayah asli Minangkabau yaitu Luhak Tanah Datar sebagai lubak tertua (sekitar Batusangkar), Luhak Agam yang berada di tengah (sekitar Bukittinggi), dan Luhak Lima Puluh kota, yang termuda (sekitar Payakumbuh). ${ }^{54}$ Lubak-lubak tersebut secara administratif berada dalam wilayah Provinsi Sumatera Barat.

Nagari Tigo Jangko merupakan salah satu nagari dari empat nagari yang ada di Luhak Tanah Datar Kecamatan Lintau Buo Kabupaten Tanah Datar. Nagari ini secara geografis terletak antara koordinat 1000-1050 Bujur Timur dan 00-50 Lintang Selatan. Nagari ini memiliki \pm 4.431 hektar yang menjadi lahan perkebunan dan pertanian. Ketinggian dari permukaan laut adalah 220-950 meter dengan curah hujan rata-ratanya $2500 \mathrm{~m} / \mathrm{th}$. Secara geomorfologis, Nagari Tigo Jangko sebagian besar wilayahnya berbentuk dataran tinggi. ${ }^{55}$ Nagari ini sebelah utara berbatasan dengan Nagari Pangian dan Lubuk Jantan Kecamatan Lintah Buo Utara. Sebelah selatan berbatasan dengan Kecamatan Sumpur Kudus. Sebelah timur berbatasan dengan Kecamatan Sumpur Kudus dan sebelah Barat dengan Nagari Taluk Kecamatan Lintau Buo. Nagari ini terdiri dari enam Jorong yaitu Jorong Rajawali, Jorong Tuanku Lareh, Jorong Abdul Rahman, Jorong Bukit Barisan, Jorong Gunung Seribu, dan Jorong Cendrawasih. ${ }^{56}$

Nagari Tigo Jangko memiliki jumlah penduduk 6.669 jiwa. Jumlah terpadat ada di Jorong Abdul Rahman sekira 1.589 jiwa. Wilayah yang

suku, ulayat kaum dan ulayat nagari. Lihat Helmy Panuh, Pengelolaan Tanah Ulayat Nagari pada Era Desentralisasi Pemerintahan di Sumatera Barat (Jakarta: Rajawali, 2012), 53-55.

54 Rantau Minangkabau tidak hanya tersebar di seluruh Nusantara dengan cara setiap perantau Minang membangun koloni di tempat perantauannya dan hidup dengan tata cara adat Minangkabau. Rantau ini bahkan sampai ke wilayah Malaysia, Singapura, Thailand selatan dan wilayah lainnya. Lihat Mochtar Naim, Merantau: Pola Migrasi Suku Minangkabau (Jakarta: Rajawali, 2013), 65.

55 Arsip dan Data Kantor Wali Nagari Tigo Jangko.

${ }^{56}$ Badan Pusat Statistik (BPS) Kabupaten Tanah Datar 2014. 
jarang penduduknya adalah Jorong Bukit Barisan. ${ }^{57}$ Profesi masyarakat Nagari Tigo Jangko rata-rata adalah petani. Ada juga yang bekerja sebagai pedagang yang terfokus di pasar Jumat Tigo Jangko yang beroperasi setiap hari Jumat. Di nagari ini sudah ada bank yang beroperasi seperti Bank Nagari, Bank BRI, dan Bank Perkreditan Rakyat. Nagari Tigo Jangko merupakan nagari yang kaya akan sumber daya pertanian dan perkebunan. Bidang pertanian yang dikembangkan adalah, jagung, padi, cokelat dan sayur-mayur. Ada juga lahan perkebunan seperti karet dan kulit/kayu manis. ${ }^{58}$ Sarana pendidikan di wilayah ini meliputi empat unit TK, lima unit SD, tiga unit SMP, tiga unit SMA, dan satu unit Perguruan Tinggi. Masjid dan musala tersebar di seluruh nagari. Beberapa di antaranya dibangun dengan cukup megah. Bagi masyarakat Minangkabau masjid tidak hanya melambangkan kekuatan nilai-nilai agama Islam tetapi juga berfungsi sebagai tempat untuk kegiatan sosial kemasyarakatan dan pemerintahan. Biasanya masjid menjadi tempat pelaksanaan musyawarah nagari yang menghimpun para ninik mamak, ulama, cadiak pandai dan komponen masyarakat lainnya.

Pemerintahan nagari selalu didasarkan pada musyawarah yang dinamakan rapek (rapat) dan dalam rapat ini segala sesuatu diperbincangkan semasak-masaknya sampai didapatkan satu keputusan yang menjadi aturan dalam adat dan dipatuhi oleh seluruh masyarakat. Musyawarah bisa dilaksanakan di balai adat maupun masjid/musala. Komponen kerapatan adat sekurang-kurangnya terdiri dari penghulu (para ninik mamak suku dalam nagari), ulama dan cerdik pandai. Tiga komponen ini disebut dalam pepatah Minangkabau dengan tungku tigo sajarangan (tungku/perapian kembar tiga). Ketiga komponen ini dalam kerapatan diikat oleh adat, agama dan undangundang yang disebut dalam pepatah dengan tali tigo sapilin (tali tiga selilitan). ${ }^{59}$ Berdasarkan penjelasan itu dapat dipahami bahwa adat Minangkabau dan agama Islam (sharî‘ah) di Minangkabau tidak bisa dipisahkan satu sama lain, bahkan keduanya saling mengisi dan melengkapi.

Agama berperan penting dalam kehidupan sehari-hari, baik dalam beribadah maupun dalam menjalin hubungan sosial kemasyarakatan. Masyarakat Nagari Tigo Jangko adalah masyarakat yang keseluruhan

\footnotetext{
${ }^{57}$ Arsip dan Data Kantor Camat Lintau Buo 2014.

${ }^{58}$ Profil Nagari Tigo Jangko Kecamatan Lintau Buo 2014.

${ }^{59}$ Ibid., 35.
} 
warganya beragama Islam dan kuat dalam memegang falsafah adat Minangkabau. Nasroen mengatakan bahwa orang Minangkabau terkenal akan agamanya yang kuat dan adatnya yang kokoh. Mereka hidup aman dan sentosa dengan menunaikan ajaran agamanya yaitu Islam dan berjalan menurut adat yang dianutnya yaitu adat Minangkabau. ${ }^{60}$ Demikian juga pada masyarakat Nagari Tigo Jangko sebagai bagian dari masyarakat Minangkabau. Masyarakat nagari ini didominasi etnis Minangkabau. Hal ini mempengaruhi kebudayaan yang berkembang di tengah masyarakat. Masyarakatnya masih menjunjung tinggi peraturan adat sehingga kebudayaan yang muncul tidak begitu terlihat beragam selain adat Minangkabau. Amir mengatakan:

Adat bagi orang Minangkabau adalah peraturan hidup sehari-hari. Jika hidup tanpa aturan, bagi orang Minangkabau namanya tak beradat. Jadi, aturan itulah yang adat dan adat menjadi pakaian sehari-hari. Bagi orang Minang duduk dan berdiri selalu beradat, berbicara beradat, berjalan beradat, makan dan minum beradat, bahkan menguap dan batukpun beradat. Semuanya disebut adat sopan santun dalam kehidupan seharihari. Adat Minangkabau tidak hanya mengatur sopan santun saja tetapi juga mengatur hal-hal mendasar seperti landasan berpikir, nilai-nilai hidup, norma, falsafah dan hukum-hukum yang harus dipatuhi. Aturanaturan itu biasanya disebutkan dalam pepatah-petitih, bidal atau pantun yang disampaikan para pemuka adat dalam pidato-pidato adat, tambotambo maupun dalam kajian-kajian adat di surau-surau. ${ }^{61}$

Dalam kajian Minangkabau modern, aturan-aturan adat disampaikan dan didiskusikan dalam forum-forum diskusi ilmiah, seminar maupun lokakarya. Dalam seminar hukum adat Minangkabau pada tanggal 21-25 Juli 1968 diungkapkan bahwa pandangan hidup adat Minangkabau begitu luas, maju, dinamis, ideal dan terstruktur sesuai dengan ajaran Islam. Buktinya, ketika agama Islam masuk ke Minangkabau, para pemangku adat khususnya dan masyarakat Minangkabau umumnya dapat menerima Islam dengan baik. Agama Islam dapat menempati hati masyarakat dan mempengaruhi pola hidup mereka. Integrasi adat dan Islam di Minangkabau bahkan dapat dilihat sampai sekarang. ${ }^{62}$

${ }^{60}$ M. Nasroen, Dasar Falsafah Adat Minangkabau (Jakarta: Bulan Bintang, 1957), 21 22.

61 Amir M.S., Adat Minangkabau: Pola dan Tujuan Hidup Orang Minang (Jakarta: Mutiara Sumber Widya, 2003), 16.

62 Mochtar Naim (ed.), Menggali Hukum Tanah dan Hukum Waris Minangkabau (Padang: Center for Minangkabau Studies Press, 1968), 119. 
Dalam sejarah Minangkabau disebutkan bahwa agama Islam masuk ke Minangkabau pada abad ke-7 Masehi melalui rantau Minangkabau Timur yaitu daerah aliran Sungai Kampar Kanan dan Kampar Kiri dan daerah aliran Sungai Batanghari dan Sungai Dareh. ${ }^{63}$ Pada waktu itu masyarakat Minangkabau hidup dalam adat matrilineal (keturunan dihitung melalui garis keturunan ibu). Adat Minangkabau itu telah ada sebelum kedatangan Islam. Oleh karena itu, terjadi proses akulturasi adat Minangkabau dan agama Islam. Terdapat ahli sejarah yang menyebut peristiwa ini dengan sebutan Islamisasi kultural. Artinya, kedatangan Islam diterima masyarakat Minangkabau dengan tidak membuang aturan adat. Proses penyatuan ini berlangsung selama berabad-abad, sehingga agama Islam dan adat Minangkabau telah hidup dan saling melindungi. Hubungan saling melindungi ini terpatri dalam pepatah adat Adat Basandi Syarak dan Syarak basandi Kitabullah. Sementara itu dalam sistem pemerintahan Kerajaan Minangkabau ditemukan corak pemerintahan yang bersifat desentralisasi berdasarkan hukum Islam dan hukum adat yang lazim disebut dengan Tungku Nan Tigo Sajarangan, Tali Nan Tigo Sapilin. Kaidah itu mewakili Raja Adat di Buo sebagai Pemegang Adat dan Limbago, Raja Ibadah di Sumpur Kudus sebagai Penegak Hukum Allah, dan Raja Alam di Pagaruyung sebagai Koordinator Adat dan Ibadat. ${ }^{64}$ Ketiga komponen di atas selalu ada dalam setiap kerapatan adat nagari, termasuk Nagari Tigo Jangko sebagai wilayah nagari yang berada di bawah kewenangan Raja Adat di Buo.

Kerapatan adat dalam nagari memiliki peran yang strategis dalam mengatur pelaksanaan pemerintahan nagari. Institusi ini memiliki kewenangan yang kuat dan dilegitimasi oleh masyarakat. Setiap penghulu sangat diperlukan agar hasil mufakat mereka di kerapatan adat nagari menjadi komunikatif, mempunyai otoritas, ditaati dan dapat menjadi milik masyarakat sukunya, terutama untuk dapat menghadapi bermacam-macam tantangan hidup dalam komunitas nagari. Pada tingkat nagari, biasanya kepentingan masyarakat suku dan kepentingan teritorial saling bertemu, saling menjaga, yang akhirnya melahirkan dan menumbuhkan kebutuhan mufakat. Kepentingan inilah yang mendorong diadakannya musyawarah dalam kerapatan adat nagari, sehingga kerapatan adat nagari menjadi lembaga tertinggi nagari yang diakui dan ditaati oleh masyarakat.

${ }_{63}$ M.D. Mansoer, Sejarab Minangkabau (Jakarta: Bhatara, 1970), 43.

${ }^{64}$ Amir M.S., Adat Minangkabau, 121. 
Banyak sekali hasil kerapatan adat yang menjadi panduan hidup masyarakat nagari di Minangkabau. Salah satu hasil kerapatan adat nagari adalah Penjara Nagari. Penjara Nagari ini dibangun di Nagari Tigo Jangko Kecamatan Lintau Buo Kabupaten Tanah Datar Sumatera Barat. ${ }^{65}$ Penjara Nagari ini dibangun di samping kantor wali nagari dan dibubuhkan nama Penjara Nagari di bagian depannya. Papan nama ini ditulis dengan huruf kapital yang cukup besar dan bisa dibaca dalam jarak yang cukup jauh. Cukup banyak terjadi pelanggaran hukum pada masyarakat Nagari Tigo Jangko. Hanya pelaku zina yang dimasukkan ke dalam Penjara Nagari tersebut. Sedangkan pelanggar hukum lainnya langsung digiring atau dibawa ke Kantor Polisi Kecamatan Lintau Buo. ${ }^{66}$ Zina tidak hanya dilarang dalam adat Minangkabau tetapi juga dilarang dalam agama Islam sebagai agama yang dianut oleh masyarakat Minangkabau.

Kerapatan adat Nagari Tigo Jangko telah menyepakati pengadaan Penjara Nagari sebagai tempat untuk mengurung orang yang berzina. ${ }^{67}$ Menurut Wali Nagari Tigo Jangko, Penjara Nagari ini didirikan pada tahun 2012. Inisiatif awal mendirikan Penjara Nagari ini berasal dari dirinya dan disambut baik oleh alim ulama, ninik mamak/penghulu, cadiak pandai dan pemuka masyarakat lainnya serta disepakati dalam kerapatan adat nagari. Anwar mengatakan:

Dalam rapat pelanggaran adat, kerapatan adat dan komponen masyarakat lainnya bermusyawarah untuk mengambil suatu keputusan mengenai persoalan tersebut. Mereka mengeluarkan pendapat dan buah pikiran masing-masing dalam mengkaji persoalan tersebut, sehingga berakhir pada suatu keputusan. Keputusan itu baru bisa dijalankan apabila telah diperoleh kata saiyo sapakaik (mufakat). ${ }^{68}$

Wujud dari mufakat adat itu adalah dituliskannya hasil musyawarah dalam rancangan peraturan nagari. Pendirian Penjara Nagari ini telah disepakati dalam kerapatan adat (musyawarah nagari) pada tahun 2012. Menurut Wali Nagari, sebagian besar masyarakat merasa terganggu dengan maraknya penyakit masyarakat di nagari tersebut, terutama terungkapnya kasus-kasus perzinaan. ${ }^{69}$ Dalam adat Minangkabau, penghulu/ninik mamak bertanggung jawab dalam

\footnotetext{
${ }^{65}$ Rancangan Peraturan Nagari Tigo Jangko No. 2 Tabun 2011 Tentang Peraturan Bidang Agama, Adat dan Kemasyarakatan dalam Kenagarian Tigo Jangko.

${ }_{66}^{6}$ Mari Yosefli (Sekretaris Wali Nagari Tigo Jangko), Wawancara, 27 Oktober 2014.

${ }^{67}$ Indra Gunalan (Wali Nagari Tigo Jangko), Wawancara, 03 Maret 2015.

${ }^{68}$ Amir M.S., Adat Minangkabau, 35.

${ }^{69}$ Data Kantor Wali Nagari Tigo Jangko Tahun 2014.
} 
menjaga anak kemenakannya dan memberi kata putus yang adil terhadap segala perselisihan di antara mereka. Dia juga berhak memberikan hukuman adat yang adil terhadap kemenakannya yang ingkar atau melanggar adat. Ketika pelanggaran adat itu merusak adat senagari, seperti perzinaan, maka untuk memberi peradilan, penghulu bermusyawarah dengan penghulu-penghulu lain dan kelengkapan nagari dalam memutuskan hukumannya. ${ }^{70}$ Penjara Nagari adalah salah satu hasil keputusan kerapatan adat dalam musyawarah nagari, karena perzinaan dipandang merusak masyarakat nagari secara keseluruhan. Selain itu Penjara Nagari ini disebut sebagai salah satu bentuk pelaksanaan falsafah adat Minangkabau Adat Basandi Syara', Syara' Basandi Kitabullah dan pituah adat Tungku Tigo Sajarangan, Tali Tigo Sapilin. Artinya, adat kebiasaan masyarakat berdasar pada hukum sharî̀'ah (hukum Islam) dan hukum sharî‘ah berdasar pada al-Qur'ân sebagai Kitab Suci umat Islam.

Senada dengan pendapat Wali Nagari Tigo Jangko, salah seorang ulama di nagari itu mengemukakan bahwa latar belakang dibangunnya Penjara Nagari ini karena banyaknya terungkap kasus perzinaan di Nagari Tigo Jangko. Misalnya, ada warga yang didapati berselingkuh dan ada anak gadis yang putus sekolah karena hamil di luar nikah. ${ }^{71}$ Dt. Penghulu Kayo mengatakan:

Dibangunnya Penjara Nagari ini karena telah banyak terjadi kasus perzinaan yang dilakukan oleh masyarakat Nagari Tigo Jangko. Penjara Nagari ini didirikan pada awal tahun 2012. Pada tahun-tahun sebelumnya tidak ada hukuman yang tegas bagi pelaku zina di nagari ini selain cemooh dan kucilan masyarakat. Perzinaan tidak hanya dilakukan oleh mereka yang telah menikah dan memiliki anak tetapi dilakukan juga oleh para remaja. Penjara Nagari ini dibangun untuk menjerakan si pelaku dan memberi contoh kepada masyarakat agar menghindari perbuatan maksiat ini yang merusak keluarga dan masyarakat. ${ }^{72}$

Salah seorang warga Nagari Tigo Jangko mengungkapkan:

Mendirikan Penjara Nagari di Nagari Tigo Jangko ini adalah bagus jika dilihat dari sisi ketenteraman dan keamanan masyarakat. Memenjarakan pelaku zina dapat mengurangi maksiat di tengah masyarakat dan menghindarkan masyarakat dari perbuatan yang dilarang agama, adat

\footnotetext{
70 Amir M.S., Adat Minangkabau, 33

${ }^{71}$ Yasiruddin (Guru Pondok Pesantren Darul Ulum Tigo Jangko), Wawancara, 10 Juli 2015.

${ }^{72}$ Dt. Paduko Kayo (Penghulu Adat di Nagari Tigo Jangko), Wawancara, 01 Juli 2015.
} 
dan negara. ${ }^{73}$

Hasil wawancara tersebut menjelaskan bahwa pemuka dan warga masyarakat sangat memberi perhatian sekaligus mengemukakan keresahan mereka atas terjadinya kasus perzinaan di tengah kehidupan mereka. Padahal adat dan agama tidak menerima perzinaan sebagai hubungan seksual yang dibolehkan. Sejak Penjara Nagari ini didirikan sudah ada warga masyarakat yang dihukum dan dipertontonkan karena tertangkap berzina. Walaupun demikian masih ada anggota masyarakat di nagari ini yang kurang setuju dengan pendirian dan proses pelaksanaan hukuman adat di Penjara Nagari tersebut sekalipun sudah disepakati dalam rapat adat. Salah seorang warga Nagari Tigo Jangko mengungkapkan bahwa: "Dari sisi kehormatan dan hak asasi manusia tidak begitu sesuai karena prosesnya terlihat melanggar hukum. Pelaku yang tertangkap itu mendapat perlakuan yang kurang beradab seperti dipukul, dihina, dan dipermalukan di depan orang banyak". ${ }^{74}$

Pendapat tersebut terakhir mengindikasikan bahwa ada masyarakat yang beranggapan bahwa pemenjaraan pelaku di luar ketentuan udang-undang tidak dibenarkan oleh hukum negara. Selain itu perlakukan masyarakat yang memukuli dan mencaci mereka juga dipandang melanggar hak asasi manusia. Akan tetapi masyarakat yang melaksanakan proses penangkapan dan pemenjaraan pelaku mengatakan bahwa dalam ajaran Islam, pelaksanaan hukuman bagi pelaku zina dipertontonkan di hadapan sekelompok orang sebagaimana diatur dalam al-Qur'ân dan hukumannya sangat berat dibanding dipenjarakan. Demikian juga mencela dan mencaci pelaku zina juga disebutkan dalam ayat al-Qur'ân. Oleh karena itu, warga yang menyetujui pemenjaraan pelaku ini beralasan kepada al-Qur'ân sebagai sendi adat Minangkabau. ${ }^{75}$

${ }^{73}$ Dewi Suryati (Warga Nagari Tigo Jangko), Wawancara, 01 Juli 2015. Dukungan masyarakat tentang perlunya penjara nagari untuk pelaku zina diungkapkan oleh banyak anggota masyarakat yang sempat diwawancarai antara bulan Mei sampai Juli 2015.

74 Hasan (Warga Nagari Tigo Jangko), Wawancara, 01 Juli 2015. Keberatan masyarakat akan adanya penjara nagari bagi pelaku zina diungkapkan oleh beberapa orang yang sempat diwawancarai pada bulan Mei sampai Juli 2015.

75 Dalam Q.S. al-Nûr [24]: 2 disebutkan Allah memerintahkan umat Islam, dalam hal ini para pemimpin, untuk melaksanakan hukuman bagi orang yang berzina di hadapan sekelompok orang Muslim. Allah juga melarang mereka untuk merasa kasihan dalam menegakkan hukum Allah. Selain itu, dalam Q.S. al-Nisâ' [4]: 16 disebutkan bahwa hukuman yang pantas bagi orang yang berzina baik antara lelaki 
Data menunjukkan bahwa dua tahun sebelum didirikan Penjara Nagari telah ada lima pasangan yang tertangkap berzina di nagari ini. Setelah Penjara Nagari didirikan pada tahun 2012, telah ada tiga pasangan warga masyarakat yang tertangkap berzina dan dihukum dengan dimasukkan ke tempat ini. Di antara mereka ada yang berstatus menikah dan ada yang sudah menjadi janda/duda. ${ }^{76}$

Dari data nagari diketahui bahwa pelaku zina yang dimasukkan ke dalam Penjara Nagari sebanyak tiga pasang (enam orang) dalam rentang waktu antara 2012 sampai tahun 2013. Di antara keenam pasang pelaku ada yang telah menikah dan ada juga yang masih lajang. Pasangan pertama masih terikat dalam status perkawinan dengan orang lain. Pelaku laki-laki dari pasangan kedua masih terikat perkawinan dengan orang lain sedangkan yang perempuan sudah berstatus janda. Pelaku laki-laki dari pasangan ketiga masih berstatus bujangan sedangkan yang perempuan sudah berstatus janda. ${ }^{77}$ Sementara itu pada tahun 2014 sampai 2015 selama proses pengumpulan data tidak terungkap kasus perzinaan yang berujung pada pemenjaraan pelaku di Penjara Nagari. Oleh karena itu, ada anggota masyarakat yang mengemukakan bahwa keberadaan Penjara Nagari ini bisa mengatasi dan mencegah terjadinya perzinaan di tengah masyarakat. $^{78}$

Proses pemenjaraan pelaku zina di Nagari Tigo Jangko tidak berlangsung lama. Apabila ada warga tertangkap tangan melakukan zina, mereka digiring ke kantor wali nagari. Pelaku laki-laki dimasukkan ke dalam Penjara Nagari yang terletak di samping kantor wali nagari, sementara yang perempuan dimasukkan ke dalam kantor wali nagari. Dalam Penjara Nagari itulah para pelaku diperlihatkan dan dipertontonkan kepada masyarakat yang ingin melihat mereka. Kondisi ini berlangsung selama beberapa jam (lebih kurang 3-5 jam). Dalam kurun waktu beberapa jam itu, ninik mamak pelaku, pemuka agama, perangkat adat dan nagari melakukan musyawarah dalam kerapatan adat untuk menentukan hukuman adat yang dapat dijatuhkan kepada si pelaku. Setelah beberapa jam diadakannya

dan perempuan maupun antara sesama jenis (laki-laki dengan laki-laki dan perempuan dengan perempuan) adalah dicaci maki.

${ }_{76}$ Data Kantor Wali Nagari Tigo Jangko tahun 2014 dan Mari Yosefli (Sekretaris Wali Nagari Tigo Jangko), Wawancara, 27 Oktober 2014.

77 Ibid.

${ }^{78}$ Hartina dan Sudin (Guru SMPN 3 Tigo Jangko), Wawancara, 30 Oktober 2014. 
musyawarah maka si pelaku dibawa oleh polisi ke kantor Polsek Kecamatan Lintau Buo yang terletak di Pangian. Pemuka masyarakat menyebutkan bahwa tujuan dipertontonkan dan diperlihatkan kepada orang banyak adalah untuk mengingatkan masyarakat agar mereka tidak terjebak dalam kasus yang sama. Pemenjaraan ini juga dimaksudkan untuk memunculkan rasa takut dalam diri masyarakat agar mereka tidak melakukan perzinaan yang dilarang oleh agama dan adat Minangkabau. Sementara itu bagi pelaku sendiri, hukuman penjara dan dipertontonkan ini bisa menjadi pelajaran dan memunculkan rasa sesal dalam dirinya. ${ }^{79}$

Ketua Pemuda Nagari Tigo Jangko mengutarakan bahwa pelaksanaan hukuman penjara bagi pelaku zina di Nagari Tigo Jangko itu sudah sejalan dengan apa yang telah diinstruksikan ataupun yang telah diatur oleh kerapatan adat nagari itu sendiri. Apabila ada warga yang tertangkap tangan melakukan zina, baik di dalam ruangan tertutup ataupun di luar ruangan maka si pelaku ditangkap secara langsung oleh masyarakat yang melihat kejadian tersebut. Sebelum si pelaku digiring ke Penjara Nagari, terlebih dahulu dimintai keterangan dari mereka di tempat kejadian. Si pelaku ditanya tentang perzinaan yang mereka lakukan. Setelah masyarakat mendapatkan pengakuan berzina dari keduanya, maka mereka digiring atau diarak ke kantor wali nagari dan pelaku lelaki dimasukkan ke dalam Penjara Nagari, sementara yang perempuan dibiarkan berada di dalam kantor wali nagari. Mereka ditempatkan di sana sampai beberapa jam atau sampai musyawarah kerapatan adat yang diikuti oleh ninik mamak, tokoh masyarakat, ulama dan aparat kepolisian selesai dilakukan. ${ }^{80}$

Proses pemenjaraan pelaku zina juga diperoleh dari pengakuan si pelaku. Misalnya seorang pelaku yang pernah dihukum di Penjara Nagari mengatakan:

Tata cara pelaksanaan hukuman masyarakat yang diberikan kepada saya setelah tertangkap tangan itu adalah sesuai dengan apa yang telah diatur atau yang telah diinstruksikan oleh nagari. Ketika saya ditangkap oleh beberapa orang warga, saya menerima beberapa pukulan. Setelah itu saya ditarik keluar rumah dan dibawa ke jalan desa dengan paksa. Saya dan pasangan digiring sepanjang jalan dari tempat kejadian menuju Penjara Nagari. Selama dalam perjalanan menuju Penjara Nagari warga terus meneriaki kami dengan kata-kata yang keras seperti tukang zina dan

Yanuhar Dt. Gindo Rajo Nan Sati (Penghulu Ampek Jinih), Wawancara, 28 Oktober 2014.

${ }^{80}$ Herman (Ketua Pemuda Nagari Tigo Jangko), Wawancara, 02 Juli 2015. 
keadaan seperti itu terus berlangsung sampai ke Penjara Nagari. Sesampai di kantor wali nagari, saya dimasukkan ke dalam Penjara Nagari bersama pasangan saya. Saya ditempatkan di sana sampai subuh. Hasil rapat perangkat adat dan nagari memutuskan hukuman adat untuk kami. Saya harus membayar denda pelanggaran adat berupa uang sebesar Rp. 500.000 ,- dan denda yang lainnya. Setelah itu saya dikeluarkan dan dibawa ke kantor polisi untuk penyelesaian masalah ini. ${ }^{81}$

Pelaku lainnya mengungkapkan:

Ketika saya tertangkap tangan oleh warga melakukan perzinaan di rumah pada malam hari, saya dan pasangan langsung ditarik paksa keluar rumah oleh warga yang menangkap saya. Sesampainya di luar rumah saya dan pasangan diinterogasi masyarakat bersama-sama. Rata-rata mereka marah dan bertanya tentang perbuatan zina yang kami lakukan. Setelah mereka mendapatkan informasi pengakuan kami berdua, maka saya dan pasangan digiring keliling kampung sampai ke Penjara Nagari di samping kantor wali nagari. Dalam perjalanan menuju Penjara Nagari, saya dan pasangan dibentak dan diteriaki warga dengan kata-kata kotor dan bahkan ada juga yang memukul saya. Setelah saya dan pasangan sampai di Penjara Nagari, kami dipertontonkan kepada warga yang datang melihat ke sana. Pada saat itu ninik mamak dan perangkat adat lain dari suku kami yang ada di Nagari Tigo Jangko langsung mengadakan rapat untuk menetapkan hukuman adat yang harus kami terima. Setelah selesai musyawarah, saya dan pasangan dikeluarkan dan diikutsertakan dalam rapat untuk memberitahukan hukuman adat yang kami terima. Ketika itu saya dan pasangan harus membayar uang adat sebanyak Rp. 500.000,- dan hukuman adat lainnya adalah kami harus menikah. $^{82}$

Berdasarkan pengakuan kedua pelaku di atas terlihat bahwa urutan pelaksanaan pemenjaraan si pelaku adalah ditangkap, diinterogasi, dipukul, digiring ke Penjara Nagari, diteriaki dengan kata-kata kotor, dan dikurung di sana sampai dengan selesainya musyawarah perangkat adat dan nagari pada waktu subuh. Oleh karena itu, si pelaku dipertontonkan dalam kantor dan Penjara Nagari selama lebih kurang satu malam.

\section{Penutup}

Penjara Nagari adalah hasil kerapatan adat Nagari Tigo Jangko. Tempat ini disediakan untuk masyarakat nagari yang tertangkap berzina. Pengakuan dari pelaku dan keterangan saksi menjadi bukti bahwa pelaku telah benar-benar melakukan zina. Hal ini menjadi

81 Anonim 1 (Pelaku Zina di Nagari Tigo Jangko), Wawancara, 01 Juli 2015.

82 Anonim 2 (Pelaku Zina di Nagari Tigo Jangko), Wawancara, 03 Juli 2015. 
dasar bagi warga untuk melaksanakan hukuman Penjara Nagari bagi pelaku zina. Bukti ini juga dijadikan alasan oleh warga, utamanya para pemuda, untuk mengarak pelaku zina sekeliling kampung sebelum ditempatkan di Penjara Nagari. Dalam perjalanan menuju Penjara Nagari tersebut pelaku mendapatkan makian dan hinaan dari masyarakat yang mengaraknya. Setelah pelaku dimasukkan ke dalam Penjara Nagari, maka ninik mamak pelaku dan para tokoh masyarakat lain di Nagari Tigo Jangko mengadakan musyawarah dalam kerapatan adat untuk menentukan hukuman adat apa saja yang dijatuhkan kepada pelaku zina. Pelaku dikurung dalam Penjara Nagari sampai beberapa jam tergantung lamanya kerapatan adat bermusyawarah untuk membicarakan hukuman adat yang dijatuhkan kepada mereka. Setelah kerapatan adat mendapat kesepakatan tentang hukuman adat yang dijatuhkan kepada pelaku zina, maka pelaku zina dikeluarkan dari Penjara Nagari. Pelaku dibawa ke tempat musyawarah untuk mendengarkan keputusan musyawarah. Apabila tidak diperoleh kesepakatan dalam musyawarah tersebut, maka pelaku dibawa oleh pihak kepolisian ke kantor kepolisian sektor (polsek) untuk penyelesaian hukum.

Disimpulkan dengan demikian bahwa Penjara Nagari di Nagari Tigo Jangko didirikan karena banyaknya terjadi kasus perzinaan yang dilakukan oleh masyarakat Nagari Tigo Jangko, baik yang telah menikah maupun yang belum menikah. Di antara tujuan didirikannya Penjara Nagari adalah untuk menjawab kekhawatiran masyarakat tentang maraknya perzinaan yang dilarang agama dan adat Minangkabau. Menurut sebagian masyarakat, Penjara Nagari ini dapat membantu menciptakan keamanan dan ketenteraman masyarakat dalam Nagari Tigo Jangko, meskipun ada juga anggota masyarakat yang kurang setuju. Akan tetapi, penulis melihat, ketidaksetujuan tersebut nampaknya hanya sebatas pada faktor "prosesi" pemenjaraan pelaku zina, bukan pada keberadaan Penjara Nagari itu sendiri.

Proses pemenjaraan pelaku yang dilakukan masyarakat terjadi secara spontan. Oleh karena itu, masyarakat cukup sulit menghindari tindakan-tindakan spontanitas yang kadang-kadang terindikasi melanggar hukum seperti memukuli si pelaku. Pada satu sisi sikap masyarakat bisa dipahami karena tingginya kebencian mereka terhadap perbuatan maksiat (perzinaan) yang dilakukan masyarakat, sementara hukuman terhadap mereka baik hukum negara dan hukum agama tidak (belum) bisa dilaksanakan. Pada sisi lain, cara ini adalah 
salah satu alternatif yang bisa dilaksanakan untuk mencegah keterlibatan masyarakat dalam perbuatan maksiat. Selain itu, pelaksanaaan hukuman adat bagi orang yang berzina menjadi jembatan pemenuhan rasa beragama yang sangat melarang dan menghukum berat pelaku zina.

Dalam perspektif hukum Islam dan hukum pidana Indonesia, Penjara Nagari ini belum sepenuhnya bisa disebut sebagai al-sijn atau penjara. Dalam hukum Islam dan hukum pidana Indonesia penjara didirikan berdasarkan aturan sharî́ah/undang-undang dan digunakan sebagai tempat untuk menghukum orang yang telah diproses hukum secara formal melalui pengadilan dan memperoleh keputusan hakim yang berkekuatan hukum tetap. Oleh karena itu, Penjara Nagari belum bisa disebut sebagai penjara seperti yang tertulis di depan ruangan. Hanya saja tempat ini bisa disebut sebagai tahanan sementara sebagai inisiatif dalam masyarakat adat sebelum pemuka nagari menuntaskan kasusnya. Selain itu pengurungan ini bisa menjaga si pelaku agar tidak dihakimi oleh masyarakat.

\section{Daftar Rujukan}

Aman, Muqowimul. Prevalensi HIV dan Sifilis serta Perilaku Berisiko Terinfeksi HIV pada Narapidana di Lembaga Pemasyarakatan dan Rumah Tahanan di Indonesia. Jakarta: Kemenkumham, 2010.

Amîr, 'Abd al-'Azîz. al-Ta' 'zîr fî̀ al-Sharî'ah al-Islâmîyah. Mesir: Dâr alBâb al-Ḥalabî wa Awlâduh, 1989.

Anonim 1 (Pelaku Zina di Nagari Tigo Jangko). Wawancara. 01 Juli 2015.

Anonim 2 (Pelaku Zina di Nagari Tigo Jangko). Wawancara. 03 Juli 2015.

Anwar, Chairul. Hukum Adat Indonesia: Meninjau Hukum Adat Minangkabau. Jakarta: Rineka Cipta, 1997.

Arief, Barda Nawawi. Kebijakan Legislatif dengan Pidana Penjara. Semarang: Badan Penerbit UNDIP, 1996.

Arief, Barda Nawawi. Pidana Penjara Terbatas: Suatu Gagasan Penggabungan antara Pidana Penjara dengan Pidana Pengawasan. Jakarta: Raja Grafindo Persada, 2002.

Arikunto, Suharsimi. Manajemen Penelitian. Jakarta: Rineka Cipta, 1993. Assiddiqie, Jimly. Pembaharuan Hukum Pidana Indonesia. Bandung: Angkasa, 1996.

'Awdah, 'Abd al-Qâdir. al-Tashrî" al-Jinầî al-Islâmî. Kairo: Maktabah Dâr al-'Urûbah, 1963. 
Bungin, Burhan. Penelitian Kualitatif. Jakarta: Kencana, 2007.

Dahlan, Abdul Azis (ed.). Ensiklopedi Hukum Islam. Jakarta: Ichtiar Baru Van Hoeve, 1997.

Gunalan, Indra (Wali Nagari Tigo Jangko). Wawancara. 03 Maret 2015. Hamzah, Andi. Sistem Pidana dan Pemidanaan Indonesia. Jakarta: Pradnya Paramita, 1993.

Hartina dan Sudin (Guru SMPN 3 Tigo Jangko). Wawancara. 30 Oktober 2014.

Hasan (Warga Nagari Tigo Jangko). Wawancara. 01 Juli 2015.

Hassûn (al), 'Alî̀ 'Abd al-Raḥmân. al-Uquibat al-Mukbtalaf 'alayhâ fî̀ Jarâiim al-Hudûd. Riyad: Dâr al-Nafầis, 2001.

Hazairin. Tujuh Serangkai Tentang Hukum (Jakarta: Bina Aksara, 1981.

Herman (Ketua Pemuda Nagari Tigo Jangko). Wawancara. 02 Juli 2015.

Jaṣsâṣ (al), Abû Bakr Aḥmad b. 'Alî al-Râzî. Aḥkâm al-Qur'ân, Vol. 2. Beirut: Dâr al-Fikr, t.th.

Kathîr, Ibn. Mukhtasar Tafsîr Ibn Kathîr, Vol. 1. Beirut: Dâr al-Qur'ân, $1393 \mathrm{H}$.

Kayo, Dt. Paduko (Penghulu Adat di Nagari Tigo Jangko). Wawancara. 01 Juli 2015.

Lamintang, P.A.F. Hukum Penitensier Indonesia. Bandung: Armiko, 1984.

M.S., Amir. Adat Minangkabau: Pola dan Tujuan Hidup Orang Minang. Jakarta: Mutiara Sumber Widya, 2003.

Mansoer, M.D. Sejarah Minangkabau. Jakarta: Bhatara, 1970.

Mâwardî (al), Abû al-Ḥasan 'Alî b. Muhammad b. Habîb. al-Aḥkâm alSultânîyah. Beirut: Dâr al-Fikr, 1966.

Miles, Mathew B. dan Hubermen, A. Michael. Analisis Data Kualitatif, terj. Tjetjep Rohendi Rohidi. Jakarta: UI Press, 1992.

Moeljatno. Kitab Undang-undang Hukum Pidana. Jakarta: Bumi Aksara, 1972.

Munajat, Makhrus. Hukum Pidana Islam di Indonesia. Yogyakarta: Bidang Akademik UIN Sunan Kalijaga, 2008.

-----. Reaktualisasi Pemikiran Hukum Pidana Islam. Yogyakarta: Cakrawala, 2006.

Naim, Mochtar (ed.), Menggali Hukum Tanab dan Hukum Waris Minangkabau. Padang: Center for Minangkabau Studies Press, 1968. 
Naim, Mochtar. Merantau: Pola Migrasi Suku Minangkabau. Jakarta: Rajawali, 2013.

Nasroen, M. Dasar Falsafah Adat Minangkabau. Jakarta: Bulan Bintang, 1957.

Naysâbûrî (al), Abû al-Ḥusayn Muslim b. al-Hajajâj. Șaḥ̣̂ Muslim. Beirut: Dâr al-Kutub al-'Ilmîyah, 2003.

Panuh, Helmy. Pengelolaan Tanah Ulayat Nagari pada Era Desentralisasi Pemerintahan di Sumatera Barat. Jakarta: Rajawali, 2012.

Perumus, Tim. KUHP dan KUHAP. Surabaya: Kesindo Utama, 2010.

Poerwadarminta, W.J.S. Kamus Umum Babasa Indonesia. Jakarta: Balai Pustaka, 2014.

Prodjodikoro, Wiryono. Asas-Asas Hukum Pidana di Indonesia. Bandung: Erwisco, 1989.

Qudâmah, Ibn. al-Mughnî, Vol. 10. Beirut: Dâr al-Kutub al-'Ilmîyah, 1985.

Remmelink, Jack. Hukum Pidana Komentar atas Pasal-pasal Terpenting dari

Kitab Undang-undang Hukum Pidana Belanda dan Paparannya dalam

Undang-Undang Hukum Pidana Indonesia. Jakarta: Gramedia Pustaka Ulama, 2003.

Șan'ânî (al), Muhammad b. al-Amîr. Subul al-Salâm, Vol. 4. Bandung: Dahlan, t.th.

Saleh, Roeslan. Kitab Undang-undang Hukum Pidana dengan Penjelasannya. Jakarta: Aksara Baru, 1987.

----. Stelsel Pidana Indonesia. Jakarta: Aksara Baru, 1987.

Sati, Yanuhar Dt. Gindo Rajo Nan (Penghulu Ampek Jinih). Wawancara. 28 Oktober 2014.

Sâyis (al), Muḥammad 'Alî. Tafsîr Ayât al-Aḥkâm, Vol. 2. t.t.: t.tp., t.th. Soedjono Dirdjosisworo, Sejarah dan Asas-asas Penologi Pemasyarakatan.

Bandung: Armico, 1991.

Sugandhi. KUHP dengan Penjelasan. Surabaya: Usaha Nasional, 1980.

Suryati, Dewi (warga Nagari Tigo Jangko). Wawancara. 01 Juli 2015.

Tirtaatmidjaja. Pokok-Pokok Hukum Pidana. Jakarta: Fasco, 1955.

Yasiruddin (Guru Pondok Pesantren Darul Ulum Tigo Jangko). Wawancara. 10 Juli 2015.

Yosefli, Mari (Sekretaris Wali Nagari Tigo Jangko). Wawancara. 27 Oktober 2014.

Yosefli, Mari (Sekretaris Wali Nagari Tigo Jangko). Wawancara. 27 Oktober 2014. 
Salma dan Solihin

Yûsuf, Zakariyâ 'Alî. al-Majmû' Sharh al-Muhadhdhab, Vol. 18. Mesir: Mața'at al-Imâm, t.th.

Zuhaylî (al), Waḥbah. al-Fiqh al-Islâmî wa Adillatuh, Vol. 6. Beirut: Dâr al-Fikr, 1989. 